\title{
UTILIZATION OF FIBEROLYTIC ENZYMES FOR IMPROVING DIGESTIBILITY IN ASSAF LAMBS FEED
}

\author{
A.M. Kholif ${ }^{1}$; H.A. El-Shanti' ${ }^{2}$ M.Kh. El-Hindy ${ }^{2}$ and A.M. Abou-Teamah ${ }^{2}$ \\ ${ }^{1}$ Dairy Science Department, National Research Centre, Dokki, Giza, Egypt \\ ${ }^{2}$ Animal Production Department, Faculty of Agriculture, Al-Azhar University, Gaza, Palestine
}

(Received 17/9/2017, accepted 1/11/2017)

\section{SUMMARY}

\begin{abstract}
$\mathrm{T}$ The three sets of 12 Assaf lambs (4 each) feed the following diets: Control, which comprised of $15 \%$ alfalfa hay and $85 \%$ concentrate feed mixture, (CFM) (on DM basis).; (T1): Control $+2 \mathrm{~g}$ fibrolytic enzymes/h/day; and (T2): Control $+4 \mathrm{~g}$ fibrolytic enzymes/h /day. The growth experiment went on for 28 weeks. Lambs were fed diets at levels of $3.5 \% \mathrm{DM}$ of body weight. The weight of animals was measured weekly before feeding at 8:00 a.m. to ascertain the average daily gain (ADG). Lambs were fasted for 12 hours before butcher, weighed just before slaughter (SW) and after complete lose blood from the body. Weights of cadaver separable fat, inward and outer offals and body fats were weighted and computed as percentage of body weight at slaughtering (SW). Blood serum specimen and rumin liquor were taken at the last day of treatment immediately before butchering from jugular vein from all lambs. The fundamental outcomes outlined as follows: Feed intake and body weight: There were no significant impact between lambs regarding feed intake, primary LBW and last LBW. Carcass traits: Dressing percentages A or B were not significantly influenced by fibrolytic enzymes treatment. Cadaver cuts: Lambs fed portions with low (T1) or high level of fibrolytic enzymes (T2) significantly raised $(\mathrm{P}<0.05)$ weights of shoulder, loin and neck than control in the diet, but did not significantly $(\mathrm{P}>0.05)$ influence weights of legs, rack, brisket and flank. Low and high level of fibrolytic enzymes reduced the percent of shoulder and rack than control, but raised the percent of loin, flank and neck than control. Edible offals: Lambs fed portions supplemented with fibrolytic enzymes (low level) $(\mathrm{T} 1)$ significantly $(\mathrm{P}<0.05)$ raised the weights of liver, kidney, tests and heart than control. Anyway, high level of fibrolytic enzymes significantly $(\mathrm{P}<0.05)$ reduced kidney, testes and heart weight than control. Total edible offals weight was s unrivalled with T1 followed by control, then T2. Nonedible parts: Lambs fed diets with high fibrolytic enzyme (T2) had higher pelt and empty gastro-intestinal part (GIP) than control group with significantly $(\mathrm{P}<0.05)$ differences. Notwithstanding, there were no significant differences $(\mathrm{P}>0.05)$ between the diverse sets relating to head, feets and GIP full. Rumen liquor: $\mathrm{pH}$ demonstrated insignificant $(\mathrm{P}>0.05)$ values by Assaf lambs fed on control, T1and $\mathrm{T} 2$ diets. All ruminal $\mathrm{pH}$ values were above 6.0. Time of sampling had a significant impact $(\mathrm{P}<0.05)$ on rumen $\mathrm{pH}$ values. Total volatile fatty acids: TVFA's concentration demonstrated higher $(\mathrm{P}<0.05)$ values by Assaf lambs fed fibrolytic enzymes supplemented-diets compared with Assaf lambs fed control. $\mathrm{NH}_{3}-\mathrm{N}$ demonstrated significant $(\mathrm{P}<0.05)$ raise by Assaf lambs fed fibrolytic enzymes supplemented-diets compared with Assaf lambs fed control. Time of sampling had a significant impact $(\mathrm{P}<0.05)$ on rumen $\mathrm{NH}_{3}-\mathrm{N}$ with an opposite trend of $\mathrm{pH}$ values. Blood components: Total protein and its fractions: Supplementing lambs diets with low level of fibrolytic enzymes $(\mathrm{T} 1)$ significantly $(\mathrm{P}<0.05)$ raised total protein and globulin contents than control or high fibrolytic enzymes level (T2). Albumin content reduced with high (T2) enzymes (T2) than the control or (T1) diets. Kidney functions (urea or creatinine), Liver functions (AST or ALT) or Lipids (triglycerides and cholesterol) and glucose metabolism: Treated rations did not significantly $(\mathrm{P}>0.05)$ affect its levels. Economical efficiency: was raised to be the highest with high fibrolytic enzymes level and was the lowest with control. From the previous results, it could be concluded that supplementation of fibrolytic enzymes as 2 or $4 \mathrm{~g} / \mathrm{h} / \mathrm{d}$ enhanced productive performance of Assaf lambs, but it was the highest with high level of fibrolytic enzymes supplementation than low fibrolytic enzymes level.
\end{abstract}

Key words: fibrolytic enzymes, growing Assaf lambs, rumin, blood serum and economical efficiency.

\section{INTRODUCTION}

There is an intense lack of traditional feed materials for animmal nutrition in Palestein. The huge feed hole between the necessities and the accessible sources constrained the organizers and nutritionists to search for non- traditional resources where there is no vying with persons, such as agricultural by- 


\section{Kholif et al.}

products which accessible around the year however are not effectively utilized or others is one of this agro-industrial by products.

Titi and Tabbaa (2004) have studied the efficiency of immediate feeding a cellulase enzyme on lamb diets digestibility. The researchers came to conclude that cellulase enzyme raised dry matter and organic matter digestibilities of treated lambs compared to those of control. A comparable pattern was watched for the crude fiber, NDF and ADF digestibility coefficients. Furthermore, Abdel-Gawad et al. (2007) assessed the impacts of fiberolytic enzymes on the in vivo nutrient digestibilities by sheep for corn stalks, wheat straw, rice straw and sugarcane bagasse. The researchers found that fiberolytic enzymes supplementation significantly raised digestibilities of DM, OM, CP, NFE, CF and hemicellulose of all roughage compared with control.

Pinos-Rodríguez et al. (2002) have researched the impact of an immediately fed exogenous fibrolytic enzyme on intake and digestion by sheep. The diets were alfalfa hay, alfalfa hay in addition to exogenous fibrolytic enzymes, ryegrass hay and ryegrass hay in addition to enzymes. The enzymes raised clear digestibility of CP, hemicellulose and NDF for alfalfa diet compared with the other diets.

Titi and Tabbaa (2004) explored the efficiency of immediate feeding of a cellulase enzyme on lamb diets digestibility. Outcomes demonstrated that cellulase enzyme raised $(\mathrm{P}<0.05)$ dry matter and organic matter digestibilities of treated lambs compared to those of control. A comparative pattern was watched for the crude fiber, NDF and ADF digestibility coefficients. Also, no distinctions were seen in crude protein digestibility between treated and control lambs.

In 2007, Abdel-Gawad et al. estimated the impacts of fiberolytic enzymes consisting of xylanase and cellulase on the in vivo nutrient digestibilities for corn stalks, wheat straw, rice straw and sugarcane bagasse. Also, the researchers observed that fiberolytic enzymes supplementation increased $(\mathrm{P}<0.05)$ digestibilities of DM, OM, CP, NFE, CF and hemicellulose of wheat straw compared with control (berseem hay), while ADL was significantly $(\mathrm{P}<0.05)$ higher for wheat straw than the control and corn stalks.

Gado et al. (2007) examined the impact of biological treatments (cellulase; rumen liquor and Cellumonas cellulasea) of bagasse to enhance the performance of Baladi lambs. The researchers showed that treated bagasse with various treatments had a significant positive impact on DM and CP digestibilities. Moreover, cellulase enzyme raised $(\mathrm{P}<0.05)$ the percent of $\mathrm{DM}$ digestibility coefficient when compared with the other treatments. Digestibility of OM, EE, NFE positively influenced by cellulase treatment.

Muwalla et al. (2007) investigated the impact of fibrolytic enzyme inclusion on nutrient digestibility of Awassi lamb fed on a high concentrate diet. They noted that DM, OM, CP, and NDF digestibilities were unaffected by the enzyme inclusion.

The current research intends to study the impact of adding cellulytic and pectolytic enzymes to diets of Assaf lambs on its productive performance.

\section{MATERIAL AND METHODS}

The present experiment was conducted in a private sheep farm in Khan Younes at Jabalia, South governorate, Gaza sector, Palestine, during the period of $1^{\text {st }}$ March 2013 to the end of October 2013. This work aimed to study the effect of adding cellulytic and pectolytic enzymes to diets of Assaf lambs on its productive performance.

\section{Growth trial}

Twelve male Assaf lambs (5/8 Awassi x 3/8 East Frisian) aging about 6 months with average weight of $26.61 \mathrm{~kg}$ were used in this experiment. Lambs were randomly divided into three experimental groups (4 lambs of each). Average initial live body weights of animals were $26.775 \pm 1.25 \mathrm{~kg}, 26.675 \pm 1.23 \mathrm{~kg}$, and $26.376 \pm 1.23 \mathrm{~kg}$ for control, T1 and T2 groups, respectively. The dietary treatments were control; control $+2.0 \mathrm{~g}$ fibrolytic enzyme/h/day $(\mathrm{T} 1)$; and control $+4.0 \mathrm{~g}$ fibrolytic enzyme $/ \mathrm{h} / \mathrm{day}(\mathrm{T} 2)$. The control diet consisted of $15 \%$ alfalfa hay and $85 \%$ concentrate feed mixture, on DM basis. Fibrolytic enzyme which imported from Japan (Tomoko® is a commercial enzymes source of Biogenkoji Research Institute - Japan) was used. The enzyme product was made from Aspergillus awamori $\left(3 \times 10^{6}\right.$ cells/g) including $1000 \mathrm{unit} / \mathrm{g}$ of acidic protease, $30 \mathrm{unit} / \mathrm{g}$ of pectinase, $25 \mathrm{unit} / \mathrm{g}$ of xylanase, $20 \mathrm{unit} / \mathrm{g}$ of $\alpha$ - 
amylase, 10 unit/g of phytase, 5 unit/g of glucoamylase and 4 unit/g of cellulase as provided from the manufacture) was obtained from Egypt. Fibrolytic enzyme was added to a portion of wheat bran then mixed thoroughly with the other concentrate ingredients. The growth trial lasted for 24 weeks. Lambs were fed at levels of $3.5 \%$ DM of body weight. Chemical compositions of the ingredients are shown in Table (1). Animals were fed individually twice a day at 8:00 a.m. and 4:00 p.m. Fresh water was available all the time round. Feed intake and body weight changes of the lambs were recorded every two weeks during the experimental period.

Table (1): Chemical composition of feed ingredients and control diet.

\begin{tabular}{lccccccc}
\hline & \multicolumn{7}{c}{ DM basis \% } \\
\cline { 3 - 8 } Item & DM $^{* *}$ & OM & CF & CP & EE & NFE & Ash \\
\hline CFM & 90.3 & 93.5 & 11.1 & 16.0 & 4.3 & 62.1 & 6.5 \\
Alfalfa hay & 88.3 & 89.6 & 30.0 & 12.6 & 2.7 & 44.3 & 10.4 \\
Control diet* & 90.0 & 92.9 & 13.9 & 15.5 & 4.1 & 59.3 & 7.1 \\
\hline
\end{tabular}

CFM: Concentrate feed mixture consisted of 49\% maize, $24 \%$ wheat bran, $12 \%$ barley, $12 \%$ soybean meal, $2 \%$ limestone and $1 \%$ sodium chloride. ${ }^{*}$ Calculated. ${ }^{* *}(D M)$ dry matter, $(O M)$ organic matter, $(C F)$ crude fiber, $(C P)$ crude protein, (EE) ether extract, (NFE) nitrogen free extract.

\section{Slaughter technique}

Animals were fasted for 12 hours before slaughter, which was performed according to the Islamic rules. Animals were weighed just before slaughter and after complete bleeding. Head, skin and feet were separated and weighed. Internal organs and offals (heart, lungs, liver, testes, spleen, kidneys and digestive tract) were removed and individually weighed. Gastro-intestinal tract full and empty weights were recorded. Fat tail of sheep was removed, weighed along with omentum, intestinal and kidney fats. Weights of carcass knife separable fat, internal and external offals and body fats were calculated as percentage of body weight at slaughtering (SW).

\section{Rumen liquor sampling}

At the last day of each experimental period, rumen liquor samples were collected by stomach tube from each animal at zero, 3 and $6 \mathrm{hrs}$ post-feeding of the ration. Samples were strained through two layers of cheese cloth and immediately used for determination of ruminal $\mathrm{pH}$ using digital $\mathrm{pH}$-meter. Rumen liquor samples were stored in glass bottles with drops of toluene and thin layer of paraffin oil and stored in a deep freeze $\left(-18^{\circ} \mathrm{C}\right)$ for analysis of ammonia nitrogen $\left(\mathrm{NH}_{3}-\mathrm{N}\right)$, and total volatile fatty acids (TVFA's).

\section{Blood sampling}

Blood samples were taken at the final day of treatment directly before slaughtering from jugular vein from all animals. Collected blood samples were centrifuged at 4000 r.p.m. for 20 min. and the supernatant was stored in glass vials at $-18^{\circ} \mathrm{C}$ till analysis.

\section{Methods of analysis}

Dry matter (DM), crude protein (CP), ether extracts (EE), crude fiber (CF) and ash of feed ingredient samples were analyzed according to A.O.A.C. (1995). Nitrogen free extract (NFE) was calculated by the difference. Values of rumen $\mathrm{pH}$ were determined using Hanna digital $\mathrm{pH}$ meter. The concentration of ammonia-nitrogen in the rumen liquor was determined by Kjeldahl distillation method (A.O.A.C., 1995). While rumen total volatile fatty acids were determined by steam distillation method as described by Warner (1964). Serum total protein was measured calorimetrically by the biuret reaction according to Gornal et al. (1949). Serum albumin was determined by calorimetric method as described by Doumas et al. (1971). Serum globulin was calculated by subtracting the values of albumin from corresponding value of total protein for each sample. The $\mathrm{A} / \mathrm{G}$ ratio was calculated by dividing the albumin value of each sample by its corresponding globulin value. Serum glucose was determined calorimetrically according to Trinder (1969). Serum alanine transferase (ALT) and aspartate transfrase (AST) were determined calorimetrically according to the method of Reitman and Frankel (1957). Serum urea was determined calorimetrically according to Fawcett and Scott (1960). Serum total cholesterol was determined calorimetrically according to Allain et al. (1974). 


\section{Kholif et al.}

\section{Economical evaluation}

The relation between feed costs and live body gain was calculated for the different experimental animal groups. The general equation by which the costs of each one $\mathrm{kg}$ of live body weight gain was calculated as follow: The cost for one $\mathrm{kg}$ gain = Total costs of feed intake US\$ / Total gain $(\mathrm{kg})$.

Economic Efficiency = Total gain price $/$ Total gain cost.

\section{Statistical analysis}

Data were statistically analyzed according to SAS (2000). The differences among groups were estimated using the general linear model (GLM) procedures. One way ANOVA procedure used to analyze the data of the main effects on growth, carcass traits, meat quality and blood serum constituents according the following model:

$$
Y_{i j}=\mu+Z_{i}+E_{i j}
$$

Where: $\mu=$ general mean, $Z_{i}=$ effect of treatment, $E_{i j}=$ experimental error. Significance was tested at $(\mathrm{P}<0.05)$ for all means separation according to Duncan $(1955)$.

\section{RESULTS AND DISCUSSION}

\section{Growth performance}

The impact of dietary fibrolytic enzyme levels on live body weight (LBW) can be discovered via comparing the outcomes of control diet (zero fibrolytic enzyme added) with those of low fibrolytic enzyme $(\mathrm{T} 1,2.0 \mathrm{~g} / \mathrm{h} / \mathrm{d})$ or high fibrolytic enzyme $(\mathrm{T} 2,4.0 \mathrm{~g} / \mathrm{h} / \mathrm{d})$. Table $(2)$ demonstrated that there was no significant impact between lambs relating to feed intake. Also, the high level of fibrolytic enzyme supplementation insignificantly $(\mathrm{P}>0.05)$ increased feed intake. Additionally, Table $(2)$ demonstrated that there was no significant impact between lambs relating to initial LBW and last LBW. Moreover, treatments with fibrolytic enzymes indicated insignificantly raises $(\mathrm{P}>0.05)$ in total LBW gain. Daily LBW gain insignificantly raised $(\mathrm{P}>0.05)$ only with high level (T2) of fibrolytic enzymes supplementation.

Table (2): Effect of fibrolytic enzymes level on live body weight (LBW) gain and feed intake of Assaf lambs.

Dissimilar superscripts at the same row mean significant differences $(P<0.05)$.

\begin{tabular}{lcccccc}
\hline \multirow{3}{*}{ Parameter } & \multicolumn{7}{c}{ Treatments } \\
\cline { 2 - 7 } & \multicolumn{2}{c}{ Control } & \multicolumn{2}{c}{ T1 } & T2 \\
\cline { 2 - 7 } & Mean & SD & Mean & SD & Mean & SD \\
\hline Initial LBW (kg) & $26.775^{\mathrm{a}}$ & 1.33 & $26.675^{\mathrm{a}}$ & 0.76 & $26.375^{\mathrm{a}}$ & 1.26 \\
Final LBW (kg) & $70.00^{\mathrm{a}}$ & 2.97 & $70.25^{\mathrm{a}}$ & 3.25 & $72.70^{\mathrm{a}}$ & 5.19 \\
Total LBW gain (kg) & $43.225^{\mathrm{a}}$ & 3.12 & $43.575^{\mathrm{a}}$ & 2.02 & $46.325^{\mathrm{a}}$ & 1.88 \\
Daily LBW gain (g) & $237.5^{\mathrm{a}}$ & 21.4 & $239.4^{\mathrm{a}}$ & 17.0 & $254.5^{\mathrm{a}}$ & 19.8 \\
Total intake (kg) & 342.5 & - & 345.9 & - & 352.1 & - \\
\hline
\end{tabular}

- $T 1=2 \mathrm{~g}$ fibolytic enzyme/h/day, $T 2=4 \mathrm{~g}$ fibolytic enzyme $/ \mathrm{h} /$ day

- Data was calculated on 182 treatment-days basis.

Bhat (2000); Saber et al. (2010) pointed that three types of cellulase enzymes are associated with the cellulase hydrolysis operation including cellobiohydrolase, endoglucanase or carboxy methylcellulase (CMC) and $\beta$-glucosidases.

Lynd et al. (2002); and Zhang and Lynd (2004) indicated that the widely acceptable mechanism for enzymatic cellulose hydrolysis includes synergistic actions by endoglucanase, exoglucanase or cellobiohydrolase and $\beta$-glucosidase. 


\section{Carcass traits}

Data relating with the carcass traits of the growing Assaf lambs fed the experimental rations condifferent levels of fibrolytic enzymes are illustrated in Tables (3-6).

\section{Dressing percentage:}

Table (3) provides a fasting weight, empty body weight, dressing (A) and (B) percent (based on fasting weight and empty body weight, respectively). Lambs fed rations with fibrolytic enzymes supplementation (T1 and T2) had higher fasting and empty body weight than those fed control ration, but the differences were not significant $(\mathrm{P}>0.05)$. These outcomes showed that fibrolytic enzymes supplementation to rations raised fasting weight by about 0.35 and $3.85 \%$, and raised empty body weight by 0.04 and $3.73 \%$ for T1 and T2, respectively. Dressing percentages, A or B were not significantly influenced $(\mathrm{P}>0.05)$ by the dietary treatment

Table (3): Effect of dietary fibrolytic enzymes levels on fasting weight, empty body weight and dressing percentages of Assaf lambs.

\begin{tabular}{lcccccc}
\hline \multirow{2}{*}{ Parameter } & \multicolumn{9}{c}{ Control } & \multicolumn{2}{c}{ Treatments } \\
& Mean & SD & Mean & SD & Mean & SD \\
\cline { 2 - 7 } & 70.00 & 5.64 & 70.25 & 3.96 & 72.70 & 3.24 \\
\hline Fasting weight $(\mathrm{kg})$ & 14.55 & 0.95 & 14.76 & 0.82 & 15.18 & 0.65 \\
Digestive tract wt. $(\mathrm{kg})$ & 55.45 & & 55.47 & & 57.52 & \\
Empty body weight* $(\mathrm{kg})$ & 35.44 & 3.08 & 35.68 & 1.88 & 36.10 & 1.87 \\
Hot carcass weight $(\mathrm{kg})$ & 50.63 & & 50.08 & & 49.66 & \\
Dressing A (\%)*** & 63.91 & & 64.68 & & 62.76 & \\
Dressing B (\%)*** & & &
\end{tabular}

Dissimilar superscripts at the same row mean significant differences $(P<0.05)$.

$T 1=2 \mathrm{~g}$ fibrolytic enzymes/ $/$ day, $T 2=4 \mathrm{~g}$ fibrolytic enzymes/h/day

* Empty body weight $=$ Fasting weight - Digestive tract weight

$* *$ Dressing $\%=$ Hot cacass weight relative to body weight

*** Dressing \% =Hot cacass weight relative to empty body weight

Researches on goats (Atti, et al. 2004) and lambs (Rocha, et al. 2004; and Woolley et al. 2005) utilizing different levels of crude protein in diets showed the similar pattern. Moreover, the outcomes of Malcolm-Callis, et al (2000) and Spears and Kegley (2002) on steers; and McBeth, et al. (2002) and Shaeffer (2006) on cattle, utilizing 20-30 mg Zn / kg DM in rations did not influence cadaver weight or dressing percentage. Furthermore, outcomes. of El-Shanti et al. (2012) on Assaf lambs confirm these outcomes.

\section{Carcass cuts:}

Shoulder, legs, loin, neck, rack, brisket and flank weights of carcass weight are illustrated in Table (4).

Outcomes in Table (4) presented that supplementing rations with low (T1) or high level of fibrolytic enzymes (T2) significantly raised $(\mathrm{P}<0.05)$ weights of shoulder, loin and neck than control in the diet, but did not significantly $(\mathrm{P}>0.05)$ influence weights of legs, rack, brisket and flank. The outcomes of ElShanti et al. (2012) on Assaf lambs agreed with these results. 
Kholif et al.

Table (4): Effect of dietary fibrolytic enzymes levels on carcass cuts of Assaf lambs.

\begin{tabular}{|c|c|c|c|c|c|c|}
\hline \multirow{3}{*}{ Parameter } & \multicolumn{6}{|c|}{ Treatments } \\
\hline & \multicolumn{2}{|c|}{ Control } & \multicolumn{2}{|c|}{$\mathrm{T} 1$} & \multicolumn{2}{|c|}{$\mathrm{T} 2$} \\
\hline & Mean & $\mathrm{SD}$ & Mean & SD & Mean & SD \\
\hline Hot carcass weight $(\mathrm{kg})$ & 35.44 & 3.08 & 35.68 & 1.88 & 36.10 & 1.87 \\
\hline Carcass cuts weight $(\mathrm{kg})$ & & & & & & \\
\hline Shoulder & $7.75^{b}$ & .0 .39 & $8.15^{\mathrm{a}}$ & 0.36 & $7.95^{\mathrm{ab}}$ & 0.44 \\
\hline Legs & $1.22^{\mathrm{a}}$ & 0.13 & $1.34^{\mathrm{a}}$ & 0.06 & $1.38^{\mathrm{a}}$ & 0.08 \\
\hline Loin & $8.00^{\mathrm{b}}$ & 0.55 & $8.74^{\mathrm{ab}}$ & .052 & $8.89^{\mathrm{a}}$ & 0.68 \\
\hline Neck & $2.66^{\mathrm{b}}$ & 0.33 & $3.30^{\mathrm{a}}$ & 0.26 & $3.11^{\mathrm{a}}$ & 0.49 \\
\hline Rack & $8.35^{\mathrm{a}}$ & 0.52 & $8.15^{\mathrm{a}}$ & 0.87 & $8.22^{\mathrm{a}}$ & 0.97 \\
\hline Brisket & $6.24^{\mathrm{b}}$ & 0.42 & $6.33^{b}$ & 0.39 & $6.80^{\mathrm{a}}$ & 0.88 \\
\hline Flank & $2.05^{\mathrm{a}}$ & 0.11 & $2.16^{\mathrm{a}}$ & 0.23 & $2.31^{\mathrm{a}}$ & 0.29 \\
\hline
\end{tabular}

* Empty body weight $=$ Fasting weight - Digestive tract weight

- Dissimilar superscripts at the same row mean significant differences $(P<0.05)$.

$T 1=2$ g fibrolytic enzymes $/ h / d a y, T 2=4$ fibrolytic enzymes $/ h /$ day

\section{Edible offals:}

Table (5) shows liver, kidney, testes, spleen, heart, lungs and trachea weights and percentages of carcass weight. The outcomes demonstrated that low level of fibrolytic enzymes supplementation (T1) significantly $(\mathrm{P}<0.05)$ raised the weights of liver, kidney, tests and heart than control. Also, high level of fibrolytic enzymes significantly $(\mathrm{P}<0.05)$ reduced kidney testes and heart weight than control. Total edible offals weight was superior with $\mathrm{T} 1$ followed by control, then T2. A similar pattern was noted with edible offals percentage (relative to empty body weight), except with testes, which demonstrated higher percent with low level of fibrolytic enzymes supplementation followed by control then high level of fibrolytic enzymes supplementation. It is important to take note of that the total edible offals percentage was most elevated with low level of fibrolytic enzymes supplementation (T1), followed by control, then high level of fibrolytic enzymes (T2). The causes of this pattern are not clear.

Table (5): Effect of dietary fibrolytic enzymes levels on edible offals (weight) of Assaf lambs.

\begin{tabular}{lcccccc}
\hline & \multicolumn{3}{c}{ Treatments } \\
\cline { 2 - 7 } Parameter & \multicolumn{2}{c}{ Control } & \multicolumn{3}{c}{ T1 } & \multicolumn{2}{c}{ T2 } \\
\cline { 2 - 7 } & Mean & SD & Mean & SD & Mean & SD \\
\hline Empty body weight* $(\mathrm{kg})$ & 55.45 & -- & 55.47 & -- & 57.52 & -- \\
Edible offals weights $(\mathrm{kg})$ & & & & & & \\
Liver & $1.16^{\mathrm{b}}$ & 0.08 & $1.29^{\mathrm{a}}$ & 0.12 & $1.24^{\mathrm{ab}}$ & 0.11 \\
Kidney & $0.19^{\mathrm{a}}$ & 0.042 & $0.19^{\mathrm{a}}$ & 0.005 & $0.16^{\mathrm{b}}$ & 0.025 \\
Testes & $0.86^{\mathrm{b}}$ & 0.11 & $1.15^{\mathrm{a}}$ & 0.023 & $0.71^{\mathrm{c}}$ & 0.06 \\
Spleen & $0.08^{\mathrm{b}}$ & 0.014 & $0.08^{\mathrm{b}}$ & 0.002 & $0.10^{\mathrm{a}}$ & 0.02 \\
Heart & $0.40^{\mathrm{ab}}$ & 0.026 & $0.43^{\mathrm{a}}$ & 0.05 & $0.33^{\mathrm{b}}$ & 0.08 \\
Lungs and Trachea & $0.84^{\mathrm{a}}$ & 0.13 & $0.84^{\mathrm{a}}$ & 0.11 & $0.84^{\mathrm{a}}$ & 0.10 \\
Total edible offal weights & 3.53 & -- & 3.98 & -- & 3.38 & -- \\
\hline
\end{tabular}

* Empty body weight $=$ Fasting weight - Digestive tract weight

- Dissimilar superscripts at the same row mean significant differences $(P<0.05)$.

$T 1=2 \mathrm{~g}$ fibrolytic enzymes/h/day, $T 2=4 \mathrm{~g}$ fibrolytic enzymes/ $/$ /day

\section{Non-edible parts:}

Non-edible parts (weight) of butcher weight are appeared in Table (6). Lambs fed diets with high fibrolytic enzyme (T2) had higher pelt and empty gastro-intestinal part (GIP) than control group with significantly $(\mathrm{P}<0.05)$ differences. Also, there were no significant differences $(\mathrm{P}>0.05)$ between the different groups concerning head, feet and GIP full. These outcomes concurred with those prominent by El-Shanti et al. (2012) on Assaf lambs affirm these outcomes. These results, likewise, concurred with 
those prominent by Atti, et al. (2004) that there were no significant differences between groups treated with various proportions of crude protein or zinc concentrations. The weight of pelt and the other components, which are rich in bone and had a low metabolic activity (head and four feet) were differed somewhat with ration. Because these organs are early maturing parts (Wallace, 1948) and thus they are less influenced by dietary in growing animals (Kamalzadch, et al. 1998).

Table (6): Effect of dietary fibrolytic enzymes levels on non-edible offals (weight) of Assaf lambs.

\begin{tabular}{lcccccc}
\hline \multirow{2}{*}{ Parameter } & \multicolumn{6}{c}{ Treatments } \\
\cline { 2 - 7 } & \multicolumn{2}{c}{ Control } & \multicolumn{2}{c}{ T1 } & \multicolumn{2}{c}{ T2 } \\
\cline { 2 - 7 } & Mean & SD & Mean & SD & Mean & SD \\
\hline Empty body weight* & 55.45 & -- & 55.47 & -- & 57.52 & - \\
Fasting weight (kg) & 70.00 & 5.64 & 70.25 & 3.96 & 72.70 & 3.24 \\
Non-edible cuts weights & $(\mathrm{kg})$ & & & & & \\
Pelt & $6.09^{\mathrm{b}}$ & 0.31 & $6.01^{\mathrm{b}}$ & 0.38 & $6.82^{\mathrm{a}}$ & 0.67 \\
Head & 3.11 & 0.37 & 2.98 & 0.23 & 3.38 & 0.09 \\
Four feet (legs) & 1.22 & 0.13 & 1.34 & 0.06 & 1.38 & 0.08 \\
GIP full & 14.55 & 0.95 & 14.76 & 0.82 & 15.18 & 0.65 \\
GIP empty & $3.23^{\mathrm{b}}$ & 0.13 & $3.56^{\mathrm{a}}$ & 0.14 & $3.63^{\mathrm{a}}$ & 0.42 \\
\hline
\end{tabular}

* Empty body weight $=$ Fasting weight - Digestive tract weight

- Dissimilar superscripts at the same row mean significant differences $(P<0.05)$.

$T 1=2 \mathrm{~g}$ fibrolytic enzymes $/ \mathrm{h} /$ day, $T 2=4 \mathrm{~g}$ fibrolytic enzymes $/ \mathrm{h} /$ day

\section{Rumen liquor}

Rumen liquor parameters are imperative indicators of rumen environment, microbial activity and subsequently rumen metabolism. The most indicative parameters decided in this research were rumen $\mathrm{pH}$, rumen total volatile fatty acids (TVFA's) and rumen ammonia nitrogen $\left(\mathrm{NH}_{3}-\mathrm{N}\right)$.

\section{Ruminal pH}

Ruminal $\mathrm{pH}$ showed insignificant $(\mathrm{P}>0.05)$ values by Assaf lambs fed on control, $\mathrm{T} 1$ and $\mathrm{T} 2$ diets (see Table, 7). All ruminal $\mathrm{pH}$ values were above 6.0 which indicate a better digestion of cellulolytic materials (Mertens, 1978). These findings might be due to the intensive fermentation operation of both nonstructural and structural carbohydrates and the production of volatile fatty acids.

Table (7): Ruminal pH of the experimental Assaf lambs (Mean \pm SD).

\begin{tabular}{|c|c|c|c|c|c|}
\hline \multirow{3}{*}{ Experimental diets } & \multicolumn{3}{|c|}{ Sampling Time } & \multirow{3}{*}{$\begin{array}{l}\text { Overall } \\
\text { Mean }\end{array}$} & \multirow{3}{*}{$\pm \mathrm{SD}$} \\
\hline & \multirow{2}{*}{ 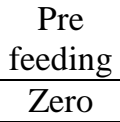 } & \multicolumn{2}{|c|}{ Post feeding } & & \\
\hline & & $3 \mathrm{hrs}$ & $6 \mathrm{hrs}$ & & \\
\hline Control & 7.05 & 6.58 & 6.83 & $6.82^{\mathrm{a}}$ & 0.06 \\
\hline $\mathrm{T}_{1}$ & 7.15 & 6.55 & 6.88 & $6.86^{\mathrm{a}}$ & 0.09 \\
\hline $\mathrm{T}_{2}$ & 7.05 & 6.50 & 6.85 & $6.80^{\mathrm{a}}$ & 0.08 \\
\hline Overall Mean & $7.08^{\mathrm{a}}$ & $6.54^{c}$ & $6.85^{\mathrm{b}}$ & & \\
\hline$\pm \mathrm{SD}$ & 0.085 & 0.086 & 0.087 & & \\
\hline
\end{tabular}

Khattab et al. (1996) and Azzaz (2009) reported that fibrolytic enzymes treatment significantly reduced ruminal $\mathrm{pH}$. 


\section{Kholif et al.}

Table (7) shows the mean values of ruminal $\mathrm{pH}$ in the different experimental diets during the different sampling times of Assaf lambs. The average $\mathrm{pH}$ values at zero time (before feeding) were 7.05, 7.15 and 7.05 for control diet, $\mathrm{T}_{1}$ and $\mathrm{T}_{2}$, respectively. Then, the $\mathrm{pH}$ values were progressively reduced to reach minimal values at $3 \mathrm{hrs}$ post feeding, being 6.58, 6.55 and 6.50 for the expected diets orderly. At 6 hrs post feeding, the $\mathrm{pH}$ values were raised to reach $6.83,6.88$ and 6.85 in the same respective order. These outcomes demonstrated that time of sampling had a significant impact $(\mathrm{P}<0.05)$ on rumen $\mathrm{pH}$ values.

Mean values of ruminal $\mathrm{pH}$ in the different experimental diets through the different sampling times of lactating Assaf lambs are shown in Table (7). The average $\mathrm{pH}$ values at zero time (before feeding) were $7.05,7.15$ and 7.05 for control diet, $\mathrm{T}_{1}$ and $\mathrm{T}_{2}$, respectively. Then, the $\mathrm{pH}$ values were gradually decreased to reach minimum values at $3 \mathrm{hrs}$ post feeding, being 6.58, 6.55 and 6.50 for the expected diets orderly. At $6 \mathrm{hrs}$ post feeding, the pH values were increased to reach $6.83,6.88$ and 6.85 in the same respective order. These results indicated that time of sampling had a significant effect $(\mathrm{P}<0.05)$ on rumen $\mathrm{pH}$ values.

\section{Ruminal total volatile fatty acids}

Table (8) presents ruminal total volatile fatty acids (TVFA's) concentration demonstrated higher $(\mathrm{P}<0.05)$ values by Assaf lambs fed $\left(\mathrm{T}_{2}\right)$ and $\left(\mathrm{T}_{1}\right)$ diets being 11.68 and $11.02 \mathrm{meq} / \mathrm{dl}$, respectively than those fed control diet $(9.42 \mathrm{meq} / \mathrm{dl})$.

Shafie and Ashour (1997) observed that the raise of TVFA's value were 23.99 and $16.98 \%$ for $\mathrm{T}_{2}$ and $\mathrm{T}_{1}$, respectively compared with control. The pattern of TVFA's values reflects the pattern of fermentation activity in the rumen).

According to Lewis et al. (1996) and Azzaz (2009) fibrolytic enzymes treatment significantly reduced ruminal $\mathrm{pH}$ and raised TVFA's concentration in the rumen.

Table (8) illustrates mean values of ruminal total volatile fatty acids (TVFA's) in the Assaf lambs fed the different experimental diets during the different sampling times. The results demonstrate the mean values of total volatile fatty acids at zero time were $7.24,8.45$ and $9.05 \mathrm{meq} / \mathrm{dl}$ for control, $\mathrm{T}_{1}$ and $\mathrm{T}_{2}$, respectively. Maximum values of TVFA's were recorded at $3 \mathrm{hrs}$ post feeding, being 11.23, 13.18 and $14.49 \mathrm{meq} / \mathrm{dl}$ for control, $\mathrm{T}_{1}$ and $\mathrm{T}_{2}$, respectively. while, at 6 hours post feeding, it was reduced to reach $9.78,10.81$ and 11.50 in the same respective order.

By and large, the data got from this research showed that TVFA's concentration was conversely related with $\mathrm{pH}$ value. Comparable results were noted by Giacomini et al. (1985); Burrin and Britton (1986); Taie (1993) and Baraghit et al. (1995). The researchers pointed out that the progress of raising ruminal TVFA's concentration paralleled with a decrease in ruminal $\mathrm{pH}$.

Hume et al. (1970); Walker and Nader (1970) and Mathison and Milligan (1971) indicated that the energetic of rumen microbial production is related to the fermentable materials degraded to TVFA's by the rumen microorganisms through digestion.

Table (8):Ruminal total volatile fatty acids concentration (meq/dl) of the experimental Assaf lambs.

\begin{tabular}{lccccc}
\hline \multirow{2}{*}{ Experimental diets } & \multicolumn{3}{c}{ Sampling Time } & \multirow{2}{*}{$\begin{array}{c}\text { Overall } \\
\text { Mean }\end{array}$} & $\pm \mathrm{SE}$ \\
\cline { 2 - 4 } & $\begin{array}{c}\text { Pre } \\
\text { feeding }\end{array}$ & \multicolumn{2}{c}{ Post feeding } & & \\
\cline { 2 - 4 } & Zero & $3 \mathrm{hrs}$ & $6 \mathrm{hrs}$ & \\
\hline Control & 7.24 & 11.23 & 9.78 & $9.42^{\mathrm{b}}$ & 0.46 \\
$\mathrm{~T}_{1}$ & 8.45 & 13.18 & 10.81 & $11.02^{\mathrm{a}}$ & 0.53 \\
$\mathrm{~T}_{2}$ & 9.05 & 14.49 & 11.50 & $11.68^{\mathrm{a}}$ & 0.51 \\
Overall Mean & $8.25^{\mathrm{c}}$ & $13.18^{\mathrm{a}}$ & $10.70^{\mathrm{b}}$ & & \\
$\pm \mathrm{SE}$ & 0.22 & 0.52 & 0.27 & & \\
\hline$a, b, c$ & :Means designated with the same letter within the same row (column) are not significantly different at $(P<0.05)$.
\end{tabular}




\section{Ruminal ammonia nitrogen $\left(\mathrm{NH}_{3}-\mathrm{N}\right)$ concentration}

According to Table $(9)$, ruminal ammonia nitrogen $(\mathrm{NH} 3-\mathrm{N})$ showed significant $(\mathrm{P}<0.05)$ increment by Assaf lambs fed $\left(\mathrm{T}_{2}\right)$ and $\left(\mathrm{T}_{1}\right)$ diets compared with Assaf lambs fed control diet. The increment of rumen ammonia nitrogen concentration with the fibrolytic enzymes treatments may be due to higher $\mathrm{CP}$ digestibility and higher fermentation rate in fibrolytic enzymes treated diets. Khorshed (2000) watched that ruminal ammonia- $\mathrm{N}$ increment in rumen of sheep and lambs when fed on rations treated with biological treatments.

Table (9) provides the mean values of ruminal $\mathrm{NH}_{3}-\mathrm{N}$ in the different experimental diets during the different sampling times of Assaf lambs. The means of $\mathrm{NH}_{3}-\mathrm{N}$ concentration at zero time among the different treatment were 13.01, 16.64 and $16.99 \mathrm{mg} / \mathrm{dl}$ for control, $\mathrm{T}_{1}$, and $\mathrm{T}_{2}$, respectively. $\mathrm{The}_{\mathrm{NH}}-\mathrm{N}$ concentrations were raised at $3 \mathrm{hrs}$ post feeding to be $22.38,25.02$ and $25.71 \mathrm{mg} / \mathrm{dl}$, then it was reduced after 6 hours to reach 18.72, 20.93 and 21.06 in the same respective order.

The differences in the mean values of $\mathrm{NH}_{3}-\mathrm{N}$ among the different sampling times were significant $(\mathrm{P}<0.05)$. The lowest values $(\mathrm{P}<0.05)$ was recorded at zero time (before feeding) (being $15.54 \mathrm{mg} / \mathrm{dl})$ and then values raised $(\mathrm{P}<0.05)$ to reach the highest value at $3 \mathrm{~h}$ post feeding (being $24.37 \mathrm{mg} / \mathrm{dl})$ and then reduced $(\mathrm{P}<0.05)$ to reach $20.24 \mathrm{mg} / \mathrm{dl}$ at $6 \mathrm{~h}$ post feeding. This pattern concurred with the pattern on goats got by El-Ashry et al. (1988).

Table (9): Ruminal ammonia nitrogen concentration (mg/dl) of the experimental Assaf lambs.

\begin{tabular}{lccccc}
\hline \multirow{2}{*}{ Experimental diets } & \multicolumn{3}{c}{ Sampling Time } & \multicolumn{1}{l}{$\begin{array}{l}\text { Overall } \\
\text { Mean }\end{array}$} & $\pm \mathrm{SE}$ \\
\cline { 2 - 4 } & $\begin{array}{l}\text { Pre } \\
\text { feeding }\end{array}$ & \multicolumn{2}{c}{ Post feeding } & \\
\cline { 2 - 4 } & Zero & $3 \mathrm{hrs}$ & $6 \mathrm{hrs}$ & \\
\hline Control & 13.01 & 22.38 & 18.72 & $18.04^{\mathrm{b}}$ & 1.07 \\
$\mathrm{~T}_{1}$ & 16.64 & 25.02 & 20.93 & $20.86^{\mathrm{a}}$ & 0.92 \\
$\mathrm{~T}_{2}$ & 16.99 & 25.71 & 21.06 & $21.25^{\mathrm{a}}$ & 1.38 \\
Overall Mean & $15.54^{\mathrm{c}}$ & $24.37^{\mathrm{a}}$ & $20.24^{\mathrm{b}}$ & & \\
$\pm \mathrm{SE}$ & 0.79 & 1.06 & 0.93 & & \\
\hline a,b.,c $:$ Means designated with the same letter within the same row (column) are not significantly different at $(P<0.05)$.
\end{tabular}

\section{Blood components}

Biochemical parameters of blood serum have been used as indicators of the nutritional and physiological status of growing lambs. The results of blood serum constituents in Assaf lambs fed the tested diets are presented in Table (10).

\section{Total protein and its fractions:}

Table (10) shows the overall means of serum total protein, albumin and globulin concentrations, and albumin/globulin ratio. The results indicate that the supplementing lambs diets with low level of fibrolytic enzymes $(\mathrm{T} 1)$ significantly raised $(\mathrm{P}<0.05)$ total protein content than control or high fibrolytic enzymes level (T2).

In any case, albumin, globulin and albumin/globulin ratio demonstrated an insignificant pattern $(\mathrm{P}>0.05)$. At the same time, albumin content reduced with high level of fibrolytic enzymes (T2) than the control or low level (T1) diets. This pattern could be attributed to the change in blood serum globulin content.

Omole (1982) indicated that the increment in serum total protein content may be associated with the increment in blood albumin concentration. Moreover, Habeeb, et al. (1989) indicated that the increment of total protein may be associated with the increment of thyroxin production, which stimulates the protein synthesis. Moreover, Freeman (1983) observed that zinc may play essential role in activation of some enzymes that are responsible of use of amino acids in protein synthesis and other physiological functions associated with metabolic rate. In addition, it is realized that the change in albumin level reflects the change in liver function. The diminishment in albumin synthesis when rations supplemented with fibrolytic enzymes (T1 and T2) could be associated with depression in anabolic hormonal secretion such 


\section{Kholif et al.}

as thyroxin (El-Masry, 1987) and insulin (Habeeb, 1987) or to the raising in catabolic hormones such as glucocorticoids (Alvarez and Johnson, 1970).

Despite the changes in serum total protein and its fractions are significant between treatments, the data were within the normal range.

Table (10): Blood serum parameters of Assaf lambs fed rations supplemented with low or high level of fibrolytic enzymes.

\begin{tabular}{|c|c|c|c|c|c|c|}
\hline \multirow{3}{*}{ Parameter } & \multicolumn{6}{|c|}{ Treatments } \\
\hline & \multicolumn{2}{|c|}{ Control } & \multicolumn{2}{|c|}{$\mathrm{T} 1$} & \multicolumn{2}{|c|}{$\mathrm{T} 2$} \\
\hline & Mean & SD & Mean & SD & Mean & SD \\
\hline Total protein $(\mathrm{g} / \mathrm{dl})$ & $6.30^{\mathrm{b}}$ & \pm 0.47 & $7.20^{\mathrm{a}}$ & \pm 0.56 & $6.30^{b}$ & \pm 0.49 \\
\hline Albumin $(\mathrm{g} / \mathrm{dl})$ & 3.80 & \pm 0.44 & 3.80 & \pm 0.38 & 3.30 & \pm 0.41 \\
\hline Globulin (g/dl) & 2.50 & \pm 0.28 & 3.50 & \pm 0.32 & 3.00 & \pm 0.38 \\
\hline A / G ratio & 1.52 & \pm 0.85 & 1.09 & \pm 0.60 & 1.10 & \pm 0.75 \\
\hline Glucose (mg/dl) & 68.33 & \pm 4.48 & 63.33 & \pm 3.28 & 65.67 & \pm 4.37 \\
\hline Urea (mg/dl) & 35.00 & \pm 1.07 & 37.00 & \pm 1.22 & 37.33 & \pm 1.28 \\
\hline Creatinine (mg/dl) & 0.78 & \pm 0.26 & 0.87 & \pm 0.35 & 0.88 & \pm 0.21 \\
\hline $\operatorname{AST}(\mathrm{u} / \mathrm{l})$ & 111.0 & \pm 1.26 & 141.0 & \pm 1.45 & 116.0 & \pm 1.32 \\
\hline $\operatorname{ALT}(\mathrm{u} / \mathrm{l})$ & 15.33 & \pm 0.62 & 16.00 & \pm 0.73 & 19.67 & \pm 0.87 \\
\hline $\mathrm{TG}(\mathrm{mg} / \mathrm{dl})$ & 110.0 & \pm 2.53 & 117.0 & \pm 2.59 & 114.0 & \pm 2.50 \\
\hline Cholesterol (mg/dl) & 87.67 & \pm 1.46 & 125.00 & \pm 1.54 & 90.00 & \pm 1.22 \\
\hline
\end{tabular}

Dissimilar superscripts at the same row mean significant differences $(P<0.05)$.

$T 1=2 \mathrm{~g}$ fibrolytic enzymes $/ \mathrm{h} /$ day, $T 2=4 \mathrm{~g}$ fibrolytic enzymes/h/day

\section{Kidney functions:}

The impact of supplementing rations with different levels of fibrolytic enzymes on blood serum urea and creatinine as indicators of kidney functions of growing Assaf lambs are shown in Table (10). The results indicate that treated rations did not significantly $(\mathrm{P}>0.05)$ affect urea level in the blood serum of lambs.

Thomas et al. (1988) reported that the serum creatinine gradually raised $(\mathrm{P}>0.05)$ with raising fibrolytic enzymes in lambs rations. Unaffected of serum urea due to fibrolytic enzymes supplementation to lambs' rations reflect the fact that the raise in blood urea nitrogen comes from raising dietary crude protein level. A raise in rumen ammonia absorption resulting in greater amounts of ammonia being utilized in liver to synthesize urea. Thus, urea concentration in blood reflects the ingestion of dietary protein.

Liver is the main site for urea formation, which contains all enzymes involved in urea production.

According to Murray et al. (1991), creatinine, the anhydride of creatine, is formed largely in muscles by irreversible non enzymatic dehydration of creatine phosphate, which is now known to be concerned with the energy mechanism of these tissues and serves primarily as a temporary store of energy. At the same time, blood serum creatinine concentration is a better indicator of glomerular filtration rate (Enger and Blegen, 1964).

In spite of the changes in serum creatinine is significant between treatments, the data were within the normal range.

\section{Liver functions:}

The results in Table (10) illustrate the influence of supplementing rations with different levels of fibrolytic enzymes on blood serum transaminases (aspartate aminotransferase, AST and alanine aminotransferase, ALT) as indicators of liver functions of growing Assaf lambs. Treated rations did not significantly $(\mathrm{P}>0.05)$ impact AST or ALT levels in the blood serum of lambs. furthermore, it could be detecting a somewhat increment in AST and ALT $(\mathrm{P}>0.05)$ with raising fibrolytic enzymes level in lambs rations. Raising the metabolism operation and growth performance of fibrolytic enzymes supplemented groups may be a response to incremented ALT activity of lambs fed diets supplemented with fibrolytic 
enzymes as noted by Davidson (1994), who reported that the function of ALT enzymes is the transfer of amino group from amino acid to synthesis another one and play an essential role in gluconeogenesis. Moreover, a raise of ALT activity is a response to the raise required for gluconeogenesis.

\section{Lipids and glucose metabolism:}

Data in Table (10) illustrated that the impact of supplementing rations with different levels of fibrolytic enzymes on blood serum triglycerides and cholesterol as indicators of lipid metabolism of growing Assaf lambs. Treated rations did not significantly $(\mathrm{P}>0.05)$ impact triglycerides and cholesterol levels in the blood serum of lambs. Also, glucose content gradually reduced $(\mathrm{P}>0.05)$ with raising fibrolytic enzymes in lambs rations. It is realized that lipids virtually have an essential role in all aspects of biological life, serving as hormones or hormones precursor, aiding in digestion, providing energy storage and metabolic fuel and acting as functional and structural components in biomembranes (Tietz, 1990).

In 1981, Noble pointed out that the dietary lipids are contributed as a source of plasma lipids as they are absorbed as non-esterified fatty acids, rapidly estrefied to triglycerol then packaged into chylomicrons and very low density lipoproteins within the intestinal mucosa, from here lipids enter the lymph and finally the venous blood.

Also, King et al. (1985) indicated that $17-29 \%$ of fatty acids synthesis attributed to acetate. Passage of dietary lipids through the rumen resulted in significant fatty acids biohydrogenation, which is reflected in a relatively high proportion of saturated fatty acids in the circulating triglycerol and non-estrefied fatty acids (Pethick and Dunshia, 1993).

From the information above it could be expected that raise metabolism and growth performance of fibrolytic enzymes supplemented groups might be considered as a response to reduced cholesterol content in blood serum of lambs supplemented with fibrolytic enzymes.

\section{Economical efficiency}

Data in Table (11) presented the findings of economical assessment of Assaf lambs as influenced by dietary fibrolytic enzymes supplementations.

These findings demonstrated that the total feed intake coasted 193.60, 191.45 and 190.70 US\$ (involving the price of supplements), while the cost of total body weight gain was $259.38,261.48$ and 277.98 US\$ for control, T1 and T2, respectively (on the basis that the cost of every kg gain equals 6.00 US\$, the cost of one $\mathrm{kg}$ mixed feed equals 0.50 US\$ and the cost of one kg fibrolytic enzymes equals 3.50 US\$). It is of important to take note that feed price per $\mathrm{kg}$ weight gain were 4.478, 4.393 and 4.116 US\$ for control, T1 and $\mathrm{T} 2$, respectively. Clearly, feed price/kg weight gain diminished with supplementing ration with fibrolytic enzymes from 4.478 to 4.393 with low fibrolytic enzymes level (about $98.1 \%$ of control) and to 4.116 with high fibrolytic enzymes level (about $91.9 \%$ of control).

So the net income was the highest with T2 (high fibrolytic enzymes level) and was the lowest with control group. At the same time the economical efficacy was raised to be the highest with T2 (high fibrolytic enzymes level) and was the lowest with control group. The relative economical efficacy raised by $2.24 \%$ and $8.96 \%$ for groups $\mathrm{T} 1$ and $\mathrm{T} 2$ above control, respectively, (Table 11) as a result of feed supplements.

Shahriarinour et al. (2011) mentioned the great interest in using cellulose wastes as feedstock during fermentation processes thereby converting low price starting materials into products of great value.

From the previous outcomes, it could be concluded that supplementation of fibrolytic enzymes as 4 $\mathrm{g} / \mathrm{h} / \mathrm{d}$ could be enhanced the economical efficacy than the low level of fibrolytic enzymes $(2 \mathrm{~g} / \mathrm{h} / \mathrm{d})$ or control diets. 
Kholif et al.

Table (11): Effect of dietary fibrolytic enzymes levels on economical efficiency of Assaf lambs fed tested rations.

\begin{tabular}{lccc}
\hline \multirow{2}{*}{ Parameter } & \multicolumn{3}{c}{ Treatments } \\
\cline { 2 - 4 } & Control & T1 & T2 \\
\hline Total body weight gain, BWG, (kg) & 43.23 & 43.58 & 46.33 \\
Total revenue (US \$) (A) & 259.38 & 261.48 & 277.98 \\
DMI kg/h/d & 1.7962 & 1.7648 & 1.7472 \\
Total DMI kg/h & 352.05 & 345.90 & 342.45 \\
Total feed intake, as fed (kg/head) & 387.2 & 380.49 & 376.70 \\
Price/kg feed (US \$) & 193.60 & 190.25 & 188.35 \\
Total of fibrolytic enzymes added (g) & 0.00 & 336 & 672 \\
Price of fibrolytic enzymes added US\$ & 0.00 & 1.176 & 2.352 \\
Total feed cost (US \$) (B) & 193.60 & 191.45 & 190.70 \\
Feed cost / kg gain (US \$) & 4.478 & 4.393 & 4.116 \\
Net revenue (US \$) (A-B) & 65.78 & 70.03 & 87.28 \\
Economic efficiency (A/B)* & 1.34 & 1.37 & 1.46 \\
\hline
\end{tabular}

* Economical efficiency expressed as the ratio between the price of total live weight gain and the price of feed consumed.

- Price of one $\mathrm{kg}$ of mixed of concentrate feed mixture and hay (85:15) as fed was 0.50 US\$, one kg fibrolytic enzymes was 3.50 US\$ and one kg live body weight was 6.0 US\$

$-T 1=2$ fibrolytic enzymes/h/day, $T 2=4 \mathrm{~g}$ fibrolytic enzymes/ $/$ day.

\section{REFERENCES}

Abdel-Gawad, M. H.; S.MM. Gad; E.H. El Sabaawy; H.M. Ali and T.M. El-Bedawy (2007). In vitro and in vivo digestability of some low quality roughages supplemented with fibrolytic enzyme for sheep. Egyptian J. Nutrition and Feeds., 10 (2) (Special Issue): 663-677.

Allain, C.C.; L.S. Poon; C.S.G. Chan; W. Richmond and P.C. Fu (1974). Enzymatic determination of total serum cholesterol. J. Clin. Chem., 20: 470-475.

Alvarez, M.B. and H.D. Johnson (1970). Urinary excretion of adrenaline and nor-adrenaline in cattle during heat and cold exposure. J. Dairy Sci., 53: 928-934.

A.O.A.C. (1995). Official Methods of Analysis of AOAC International, $16^{\text {th }}$ Ed. Vol.1, "Agricultural, Chemicals, Contaminants, Drugs". Washington, D.C., USA, 521p.

Atti, N.; H. Rouissi and M. Mahouachi (2004). The effect of dietary crude protein level on growth, carcass and meat composition of male goat kids in Tunisia. Small Ruminant Research, 54: 89-97.

Azzaz, H.H., (2009). Effect of Cellulytic Enzymes Addition to Diets on the Productive Performance of Lactating goats. M.Sc. Thesis, Fac. Agric., Cairo Univ., Egypt, 141 p.

Baraghit, G. A.; B.M. Ahmed; A.F. Shehata and H.T. Taie (1995). Effect of clover intake by sheep and Assaf lambs on digestion Kinetics. Proc. $5^{\text {th }}$. Sci. Conf. Animal Nutrition, Ismailia, Egypt, 356 p.

Bhat, M.K. (2000). Cellulases and related enzymes in biotechnology. Biotechnol. Adv., 18: 355 - 383.

Burrin, D.G. and R.A. Britton (1986). Response to monensin in cattle during sub acidosis. J. Anim. Sci., 63: 888 .

Chen, J.D.; J.F. Wang and K.J. Li (1989). Nutritional problems and measures in elite and amateur athletes. Am. J. Clin. Nutr., 49: 1084.

Chinedu, S.N.; A.O. Eni; A.I. Adeniyi and J.A. Ayangbemi (2010) Assessment of growth and cellulase production on wild-type micro fungi isolated from Nigeria. Asian J. Plant Sci., 97: 118-125.

Davidson, A.L. (1994). Amino acids degradation. In: "Biochemistry" (Eds. Davidson, V.L. and Sittman, D.B.), Harwal Publishing, Philadelphia, London, Tokyo, p. 457-470.

Doumas, B.; W. Wabson and H. Biggs (1971). Albumin standards and measurement of serum with bromocresol green. Clin. Chem. Acta, 31:87.

Duncan, D.B. (1955). Multiple range and multiple F tests. Biometrics, 11: 1. 
El-Ashry, M.A., H.A. El-Alamy, O.A. Salem and A.M. Kholif (1988). Rumen parameters of lactating goats as affected by different concentrate: roughage ratios. Annals Agric. Sci., Moshtohor, 26: 217 232.

El-Masry, K.A. (1987). The role of thyroxin in improving productivity of heat stressed animals with different techniques. Ph. D. Thesis, Fac. Agric., Zagazig Univ., Egypt, 145pp.

El-Shanti, H.A., A.M. Kholif, M.A. Hanafy, K.J. Al-Shakhrit and I.M. El-Hasaynah (2012). Effect of thiamin supplementation to diet on the productive performance of lambs. 13 Scientific Coference on Animal Nutrition, Feb., 2012, Sharm El-Sheikh, South Sinia, Egypt. Egypt. J. Nutrition and Feeds, 15(1)(Special Issue):. 67-80

Enger, E. and E.M. Blegen (1964). Clinical Biochemistry of Domestic Animals. $4^{\text {th }}$ Edition, Academic Press, Inc., 170pp.

Fawcett, J. K. and Soctt, J. E. (1960). A rapid and precise method for the determination of urea. J. Clin. Path., 13:156-159.

Freeman, B.M. (1983). Physiology and Biochemistry of Domestic Fowl, Academic Press, New York, London, 4:181.

Gado, H. M.; Metwally, H. M.; EL-Basiony, A. Z.; Soliman, H. S. and Etab Abd El Galil, R. I. (2007). Effect of biological treatments on sugarcane bagasse digestibility and performance of baldi Assaf lambs. Egyptian J. Nutrition and Feeds, 10 (Special Issue.2): 535-551.

Giacomini, D. G.; J.H. Clark and J.L. Vicini (1985). Effect of sequence of feeding on ruminal fermentation, milk yield and milk composition. J. Dairy Sci., 68 (suppl. 1):1342.

Gornal, A.G.; C.J. Bardawill and M.M. David (1949). Determination of serum proteins by means of biuret reaction. J. Biol. Chem., 177: 751-766.

Habeeb, A.A. (1987). The role of insulin in improving productivity of heat stressed farm animals with different techniques. Ph. D. Thesis, Fac. Agric., Zagazig Univ., Egypt, 134pp.

Habeeb, A.A.; M.S. Ayyat and S.M. Basiuny (1989). Thyroid function, some blood constituents and fattening performance of rabbits as affected by thyroxin treatments. $3^{\text {rd }}$ Egyptian-British Conf. Animal, Fish and Poultry Production. Alex., Egypt, 2:1017-1025.

Kamalzadch, A.; W.J. Koops; Van Bruchem; S. Tamminga and D. Zwart (1998). Feed quality restriction and compensatory growth in growing sheep: development of body organs. Small ruminants Res., 29: 71-82.

King, K.R.; J.M. Goodin and E.F. Annison (1985). Acetate metabolism in the mammary gland of the lactating ewes. Aust. J. Biol. Sci., 38:23.

Khattab, H. M.; S.M. Abdelmawla and A.M. Singer (1996). Nutritional evaluation of rumen content as a slaughter house waste in sheep rations. Egyptian J. Anim. Prod., 33. (Suppl. Issue): 173.

Lewis, G.E.; C.W. Hunt; W.K. Sanchez; R. Treacher; G. Pritchard and P. Feng (1996). Effect of directfed fibrolytic enzymes on the digestive characteristics of a forage-based diet fed to beef steers. J. Anim. Sci., 74:3020-3028.

Lynd, L.R.; P.J. Weimer; W.H. van Zyl and I.S. Pretorius (2002). Microbial cellulose utilization: fundamentals and biotechnology. Microbiol. Biol. Rev., 66:506-77.

Malcolm-Callis, K.J.; G.C. Duff; S.A. Gunter; E.B. Kegley and D.A. Vermeire (2000). Effects of supplemental zinc concentration and source on performance, carcass characteristics, and serum values in finishing beef steers. J. Anim Sci., 78: 2801-2808.

Mathison, G.W. and L.P. Milligan (1971). Nitrogen metabolism in sheep. Br. J. Nutr., 25: 351.

McBeth, L.J.; C.R. Kerhbiel; J.J. Martin; C.A. Strasia; D.R. Gill; C.E. Markham; R.E. Peterson; J.M. Reeves; S.S. Swanek and C.K. Swenson (2002). Effect of zinc level and source on finishing cattle performance and carcass traits. Okla. Agr. Exp. Sta. Res. Rp., P-993: 24.

Mertens, D.R. (1978). Effect of buffers upon fiber digestion. In: Regulation of Acid-Base Balance Symposium", Arizona Inn, Tucson, Arizona, USA, pp.43-108.

Murad, H.A. and H.H. Azzaz (2010). Cellulase and dairy animal feeding. Biotechnology, 9:238-256.

Murray, R.K.; D.K. Granner; P.A. Mayes and V.W. Rodwell (1991). Harper's Biochemistry. $22^{\text {nd }}$ Edition, Appleton and Lange, Norwalk, Connecticut/Los Altos, California, p. 657-658. 


\section{Kholif et al.}

Muwalla, M.M.; S.G. Haddad and Hijazeen, (2007). Effect of fibrolytic enzyme inclusion in high concentrate fattening diets on nutrient digestibility and growth performance of Awassi lambs. Livestock. Sci., 111:255.

Noble, R.C. (1981). Digestion, absorption and transport of lipids in ruminants. In lipid metabolism in ruminant animals. (Christie, W. W., Ed.). Pergamon Press, Oxford, 57.

Omole, T.A. (1982). The effect of level of dietary protein on growth and reproductive performance in rabbits. J. Applied Rabbit Res., 5(3): 83-88.

Pethick, D.W. and F.R. Dunshea (1993). Fat metabolism and turnover, In quantitative aspects of ruminal digestion and metabolism. (Frobes, M. and France, J. Edn.), CAB International, 291.

Pinos-Rodriguez, J. ; S. S. González; G.D. Mendoza ; R. Bárcena; M. A. Cobos; A. Hernández and M. E. Ortega (2002). Effect of exogenous fibrolytic enzyme on ruminal fermentation and digestibility of alfalfa and rye-grass hay fed to lambs. J. Anim. Sci., 80:3016.

Reitman, S. and S. Frankel (1957). Calorimetric method for the determination of serum glutamicoxaloacetic and glutamic-pyruvate transaminase. Am. J. Clin. Path., 28:56.

Rocha, M.H.M.; I. Susin; A.V. Pires; J.S. Fernandes and C.Q. Mendes (2004). Performance of Santa Ines lambs fed diets of variable crude protein levels. Scientia Agrícola, 61(2):141-145.

Saber, W. I. A.; N. E. A. El-Naggar and S. A. Abd Al-Aziz (2010). Bioconversion of lignocellulosic wastes into organic acids by cellulolytic rock phosphate- solubilizing fungal isolates grown under solid- state fermentation conditions. Res. J. Microbiol., 5:1-20.

SAS (2000). Statistical Analysis System. SAS Users guide statistics. SAS Institute Inc., Cary, NC.

Shaeffer, G.L. (2006). Evaluation of basic zinc chloride as a zinc source for cattle. M. Sc. Thesis, Faculty of Animal Science, North Carolina State University, 40pp.

Shafie, M.M. and G. Ashour (1997). Influence of heat and formaldehyde treated proteins on nitrogen metabolism and wool growth rate of adult sheep. Agroanimalia., 5:56.

Shahriarinour, M.; M.N.A. Wahab; A. Ariff and R. Mohamad (2011). Screening, isolation and selection of cellulolytic fungi from oil palm empty fruit bunch fibre. Biotechnology, 10: 108-113.

Spears, J.W. and E.B. Kegley (2002). Effect of zinc source (zinc oxide vs. zinc proteinate) and level on performance, carcass characteristics, and immune response of growing and finishing steers. J. Anim. Sci., 80: 2747-2752.

Taie, H.T. (1993). Digestibility and rumen fermentation as affected by urea treated corn cobs in comparison to berseem hay in fistulated sheep. Minofiya J. Agri. Res., 14: 239.

Tietz, N. W. (1990). Clinical guide to laboratory tests. $2^{\text {nd }}$ ed. W. B. Saunders Co.

Titi, H. and W.F. Lubbadeh (2004). Effect of feeding cellulase enzyme on productive responses of pregnant and lactating ewes and Assaf lambs. J. Small Ruminant., 52: 137-143

Titi, H.H. and M.J. Tabbaa (2004). Efficacy of exogenous cellulase on digestibility in lambs and growth of dairy calves. Liv. Prod. Sci., 87: 207 - 214.

Trinder, P. (1969). Determination of blood glucose using 4-amino phenazone as oxygen acceptor. J. Clin. Pathol., 22 (2): 246.

Walker, R.A. and C.J. Nader (1970). Rumen microbial protein synthesis in relation to energy supply: diurnal variation. Asut. J. Anal., 1: 747.

Wallace, L.R. (1948). The growth of lamb before and after birth in relation to the level of nutrition. J. Agric. Sci., 39: 93-103.

Warner, A. C. J. (1964). Production of volatile fatty acids in the rumen. Methods of Measurements. Nutr. Abst. Rev., 34:339.

Woolley, D.K.; B.J. May and M.W. Salisbur (2005). Effect of protein level on feedlot performance and carcass characteristics of Taxas Rambouillet feeder lambs. Proceedings, Western Section, American Society of Animal Science, 56: 139-142.

Zhang, Y.H.P. and L.R. Lynd (2004). Toward an aggregated understanding of enzymatic hydrolysis of cellulose: noncomplexed cellulase systems. Biotechnol Bioeng., 88:797-824. 
عبدالقادر محمود خليف و حاتم عايش الثنطى و محم خليل الهندى و اسعد محمد ابو طعيمه

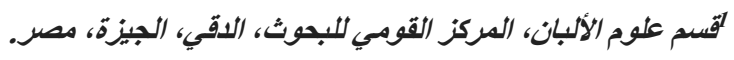

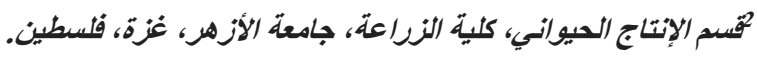

صمعت هذه التجربة لاراسة تأثير : إستخدام الإنزيمات المحللة للأليات (بمستويين: منخفض أو عالى) لتحسين الهضم فى غذاء

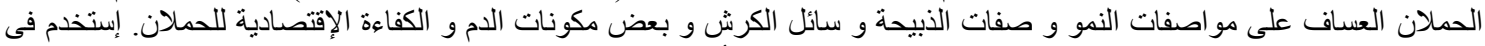

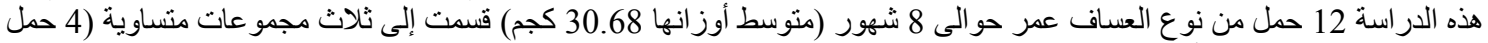

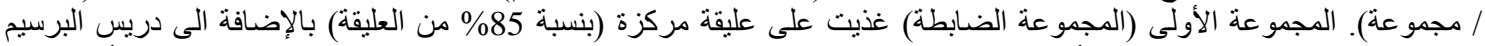

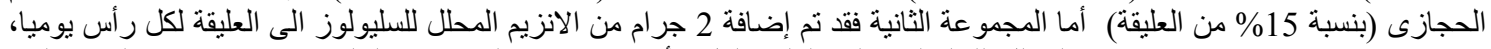

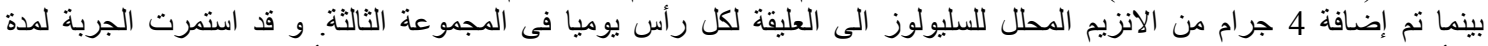

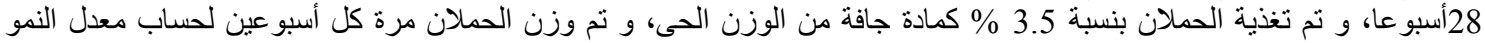

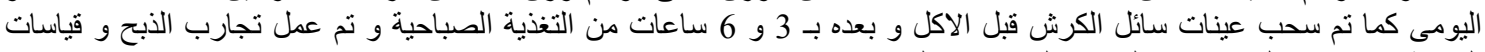

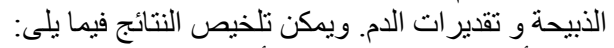

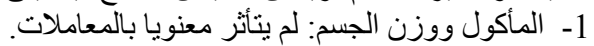

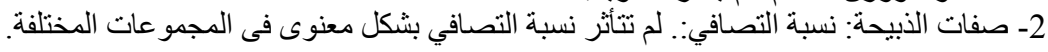

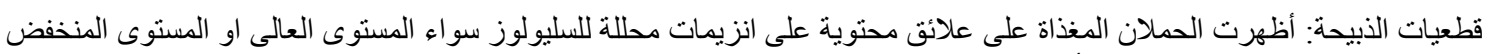
زيادة معنوية (على مستوى 5\%) فى أوزان الكتف و و الخاصرة والرقبة على عنها فلى المغذاة على عليقة المقارنة،

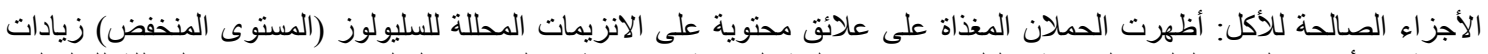

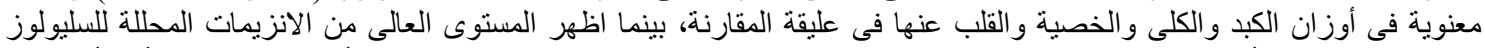

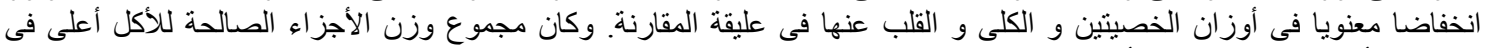

المعاملة الأولى يليها المقارنة و أخيرا المعاملة الثانية.

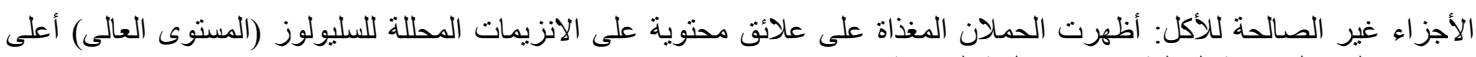

اوزان فى القناة الهضمية الخالية عنها مع عليقة المقارنة معنويا.

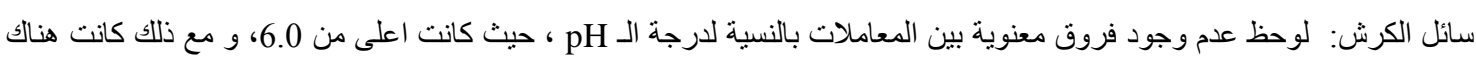

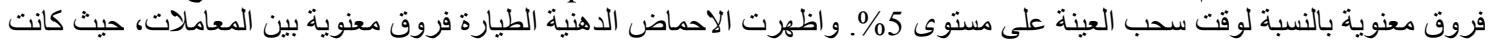

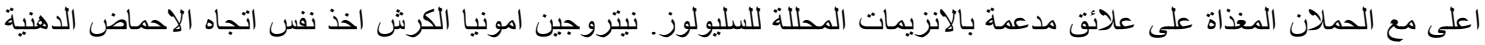

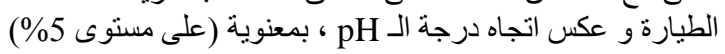

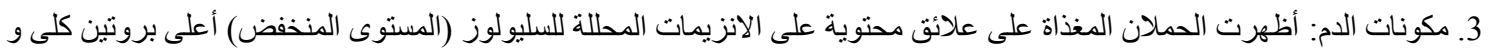

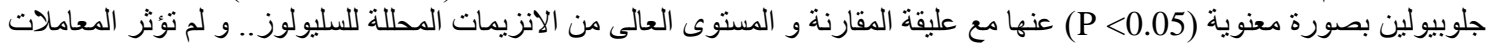

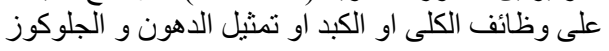
الكفاءة الاقتصادية: كان صافي الإير ادات أعلى مع المستوى العالى من الانزيمات المحللة للسليولوز وكان الكان أدنى مع المجمو عة الدقارنة، في نفس الوقت تم زيادة الكفاءة الاقتصادية أيضا.

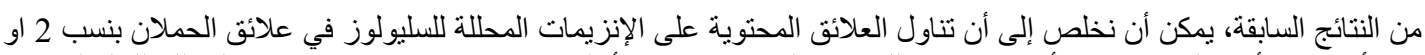

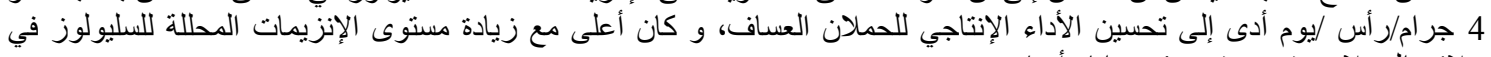

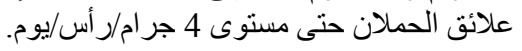

الكلمات الدالة: انزيمات محلة للسليولوز، حملان عساف، نمو ـ مو اصفات ذبيحة، سائل كرش، مكونات دم، جدوى اقتصادية. 